\title{
Teaching English as a Second Language in Vietnam: Transitioning from the Traditional Learning Approach to the Blended Learning Approach
}

\author{
Ho Thi Thao Nguyen ${ }^{1,3, *}$, Subarna Sivapalan ${ }^{1}$, Pham Hung Hiep ${ }^{2}$, Pham Thi Van Anh $^{3}$ \\ and Nguyen Thi Mai Lan ${ }^{3}$ \\ ${ }^{1}$ Centre for Excellence in Teaching \& Learning, Universiti Teknologi PETRONAS Bandar \\ Seri Iskandar, Perak, MALAYSIA \\ ${ }^{2}$ Center for Research and Practice on Education, Phu Xuan University, Vietnam \\ ${ }^{3}$ FPT University, Hanoi, VIET NAM
}

\begin{abstract}
Although blended learning (BL) has been utilized in English language teaching globally for the past few decades, it is a new phenomenon in the Vietnamese context. Little research has been done to simultaneously investigate how students and lecturers perceive blended learning implementation for English as a foreign language (EFL) teaching and learning in Vietnam, particularly within the higher education context. This study thus aims to investigate lecturers' and students' perspectives on BL implementation in an English Fundamentals course at a polytechnic in Hanoi, Vietnam. Data was collected via an online survey of 1500 non-English majors in the Fall 2019 semester and via interviews with 5 fulltime EFL lecturers. The findings revealed that lecturers and students had positive perceptions of BL. For lecturers, the implementation of BL impacted their teaching approach and shifted the teaching of grammar and vocabulary from face-to-face to self-studying grammar and vocabulary using online lessons, devoting more in-class time to practicing speaking. Students meanwhile revealed that BL helped them develop self-autonomy of learning.
\end{abstract}

Keywords: Blended learning, English language teaching, Polytechnic

\section{Introduction}

BL has been considered as an effective approach to make use of students' lack of exposure to the English language both inside and outside English classes (Hoang, 2015). Regarding the pedagogies, the utilization of a BL mode might "enable teachers to respond to a wide variety of students' learning needs, to scaffold learning processes, and to facilitate active, reflective and collaborative learning" (Rubio \& Thoms, 2014).

\footnotetext{
*Corresponding author: anhptv6@fe.edu.vn
} 
To align with global learning trends, the Vietnamese Government decided to transform the education landscape in Vietnam from the traditional learning approach to the $21^{\text {st }}$ learning approach, via BL. BL targets to improve instruction, foster "active, creative and independent learning" of students (Vietnamese Government 2012). The studied institution, which is a vocational institution (mentioned as the polytechnic in this paper) belonging to one of the biggest information technology groups in Vietnam, has been implementing BL in their training programs since 2012. In 2012, English was the first subject to pilot BL at the polytechnic. The lecture slides were rather simple with the content transferred from textbooks to slides. These slides were later uploaded into the Learning Management System (LMS). This platform supported all forms of content, including learning materials, videos, audios, quizzes/tests and so on. Students with their own accounts could access online lessons and download learning materials as well as participate in online forums to study online lessons and complete all required exercises/activities before class by themselves. However, most of them failed to complete their tasks due to the lack of motivation, student engagement and interaction between instructors and students, leading to the temporary halt of BL at the institution in 2015.

At the beginning of 2019, the wave of digital transformation in education rose at the polytechnic. Again, BL was chosen and utilized for many courses including English. However, there were a number of differences between the two versions of BL courses in 2012 and 2019. The 2019 BL courses had been uploaded into a new platform named Course Management System (CMS) that has more functions than the LMS in 2012. Each online lesson was followed by a quiz to assess students' comprehension of the lesson. Face-to-face classes were used to practice and foster their communication skills rather than to evaluate if they completed the online lesson prior to the class. Mid-term and final tests (listening, reading, grammar and vocabulary) were attempted through the online system, and only speaking skill was tested offline.

Little research has been conducted to simultaneously explore how students and lecturers perceive blended learning (BL) implementation for teaching English in general. Meanwhile, there have been very few studies of the perceptions of lecturers and students on BL implementation for teaching English as a foreign language (EFL) in Vietnamese educational institutions in particular. (see appendix)

Therefore, the researchers conducted this study focusing on how the polytechnic lecturers and students perceive the implementation of BL at the institution.

The research questions are as follows:

1. What is the status of implementing BL in English courses at the polytechnic?

2. How do polytechnic lecturers perceive the implementation of BL in English courses?

3. How do polytechnic students perceive the implementation of BL in English courses?

Data was collected through individual interviews with English lecturers and an online survey with students at the polytechnic.

\section{Literature Review}

There has been an increase in studies on blended learning in teaching English as researchers have been trying to utilize this model in teaching English as second/foreign language (ESL/EFL) (Albiladi \& Alshareef, 2019). Accordingly, a number of definitions have been given to blended learning. 
Several definitions have been used to describe BL. It was first used in the corporate environment as "a strategy to support employees' work and study at the same time" (Sharma 2010). Following this, "the use of BL was advocated in the educational setting as a result of the approachability of computer technology in and outside the classroom, the expansion of teaching methods supported by Information and Communication Technology (ICT)" (Hong and Samimy 2010), and the ineffectiveness found in fully-online courses (McDonald, 2008). For Partridge, Ponting and McCay (2011), "BL courses in higher education can be placed somewhere on a continuum between fully online and fully face-to-face courses" (p.3).

In some instances, the distribution of course content taught online is used to define blended learning. According to Allen, Seaman and Garrett (2007), "a course is called blended learning if the percentage of course content delivered online falls from $30 \%$ to $79 \%$ ". Within this study, the authors follow the definition of Allen, Seaman and Garrett (2007). According to this definition, the design of the English course at the polytechnic is qualified as BL since we have $70 \%$ of the course content designed for students to study online.

\section{Benefits of blended learning}

There is limited literature on blended learning in Vietnam, which leads to a possibility that there could be considerable differences in the ways in which blended learning is interpreted and implemented (Hoang 2015). At the studied institution, blended learning is interpreted as the reduction of face-to-face hours and cutback time replaced by the online portion. No matter how blended learning is understood, it is gaining worldwide prominence due to its key benefits to three main stakeholders of EFL education including students and teachers.

\section{For EFL students}

First, with blended learning, students are equipped with rich sources of language learning materials, which are insufficient in some EFL contexts (Gruba and Hinkleman 2012). Second, in blended learning courses, the collaboration between students and students, between students and teachers occurs more often (Taylor and Newton 2013), and what students obtain from blended learning is active and reflective learning. Finally, students are provided with the flexibility to learn from home or at their own pace (Moskal and Cavanagh 2013).

\section{For EFL lecturers}

First, blended learning implementation can assist lecturers to facilitate students to interact and collaborate in learning the English language (Hoang, 2015). Second, Joosten (2014) noted that "teachers are offered opportunities to understand students' learning individually to enhance their active and reflective learning" in blended learning courses. Particularly, teachers and students can communicate and interact via online tools during the self-study time (Vaughan et al., 2013) so that teachers can gain more understanding of their students' learning regarding "what students know, how they know it, and how they feel about that aspect of their experience" (Murphy, 2008, p. 31). As a result, it is easier for teachers to design relevant language input activities and provide well-timed feedbacks to promote students' active and reflective learning in EFL courses.

\section{Challenges of blended learning implementation}

Despite the above benefits that BL brings to both students and teachers, a number of challenges are seen.

\section{Challenges faced by students}


First, students have to be "active and responsible for their learning in order to complete and gain success in blended learning courses" (Alebaikan and Troudi, 2010). However, in the early years at schools, most of the students find it challenging to study by themselves (Hoang, 2015) due to their prior experience at high schools focusing on teacher-centered classrooms rather than student-centered classrooms (Alebaikan and Troudi, 2010).

Second, students' lack of experience in using computers and web-based technology prevents them from completely utilizing online courseware (Hoang, 2015). Technical problems including "unfamiliarity with additional software or Internet connection errors," also cause trouble to students (Moskal and Hartman, 2013).

In Vietnam, the student-related issues in blended learning implementation seem to be more because students are accustomed to passive learning, regardless of regional differences, where lectures are the "controllers of the knowledge, preventing students from their own decision making in the study" (Hoang, 2015).

\section{Challenges faced by lecturers}

In order to enhance the student engagements, lecturers need to "move beyond their own acquired"- and to be willing to explore new "methodologies, tools, and approaches to EFL teaching" (Johnson and Marsh, 2014). Nevertheless, it is known that in previous research that "many teachers pay little attention to students' self-study beyond class time or find it difficult to integrate students' self-study process into face-to-face class' activities" (Stracke, 2007). Additionally, some lecturers are unsure about the blended learning courses' quality due to the extra workload and the unfamiliarity with using some technology-based tools during blended learning courses" (Betts, 2014).

In particular, challenges faced by Vietnamese lecturers might be clearer for the following reasons. The dominant classrooms are teacher-centered, focusing on improving students' language acquisition regarding grammar and vocabulary. Importantly, for ICT application, lecturers lack training programs on implementing technology-based applications in their instruction, which makes them inconfident and untrustworthy in approaching blended learning (Hoang, 2015).

\section{Methodology}

\subsection{Overview research approaches}

This study employed a triangulation mixed method. Ivankova, Creswell and Stick (2006) mentioned that "a mixed-method approach could help researchers conduct research with clean designs and more rigorous procedures and ultimately produce more meaningful study outcomes" (p.18). The aim of the triangulation was to discover something that would have been missed if only a qualitative or a quantitative approach had been applied (Modell, 2005). Particularly, this study conducted a survey to gather data from student respondents $(n=1500)$ and individual interviews with lecturer respondents $(n=5)$ at the same time.

\subsection{Research Participants}

The participants for the survey consisted of 1500 non-English major fresh students at the polytechnic. They enrolled in the English Fundamentals (ENT1125) course in the Fall 2019 semester at the institution's Hanoi campus. This course consisted of 64 online hours and 18 
offline hours. Respondents' English proficiency is at the beginner's level. All respondents volunteered to be part of the study.

Five full-time lecturers volunteered to participate in the individual interviews. The demographics, qualifications and teaching experience of the 5 full -time lecturers are shown in Table 1.

Table 1. The characteristics of lecturers in individual interviews

\begin{tabular}{|c|l|l|l|c|}
\hline Code & Gender & Age & \multicolumn{1}{|c|}{ Highest Academic Qualifications } & $\begin{array}{c}\text { Teaching } \\
\text { experience at the } \\
\text { polytechnic }\end{array}$ \\
\hline $\begin{array}{c}\text { Lecturer } \\
1\end{array}$ & Female & 29 & $\begin{array}{l}\text { Masters degree in English Language Teaching } \\
\text { Methodology }\end{array}$ & 2018 - present \\
\hline $\begin{array}{c}\text { Lecturer } \\
2\end{array}$ & Female & 31 & $\begin{array}{l}\text { B.A in English Language Teaching } \\
\text { Methodology }\end{array}$ & 2012 - present \\
\hline $\begin{array}{c}\text { Lecturer } \\
3\end{array}$ & Female & 30 & B.A in English for Business & 2012 - present \\
\hline $\begin{array}{c}\text { Lecturer } \\
4\end{array}$ & Female & 38 & $\begin{array}{l}\text { Masters degree in English Language Teaching } \\
\text { Methodology }\end{array}$ & 2012 - present \\
\hline $\begin{array}{c}\text { Lecturer } \\
5\end{array}$ & Female & 31 & $\begin{array}{l}\text { Masters degree in English Language Teaching } \\
\text { Methodology }\end{array}$ & 2012 - present \\
\hline
\end{tabular}

\subsection{Data collection}

The questionnaire was developed using Google Forms and the link was then shared with the respondents. A five-point Likert scale questionnaire (from completely disagree to completely agree) was used to elicit data from the participants. The questionnaire was divided into three main sections. Section 1 consisted of seven questions about the overall course such as course orientation, course syllabus, courseware and course assessment. Section 2 involved five questions about the instructors' teaching strategies and techniques. The final section included three open-ended questions aiming to collect students' feedback on the effectiveness of BL implementation in their English course, as well as their suggestions to improve BL in teaching English in the future.

A group of 5 full-time lecturers was involved in the interview session, which aimed to gauge their perceptions about their own background on BL, BL implementation, BL impacts on lecturers' delivery and student learning, the challenges and the potentiality of BL in the future. Each individual interview took place around 30 minutes. All conversations were recorded with permission and transcribed for further analysis.

\section{Findings}

\subsection{Interview findings: Perspectives from polytechnic lecturers}

Interviews revealed several key issues in implementing BL at the polytechnic, which is summarized as below:

(1) The polytechnic's Board of Management (BOD) assumed that almost all English lecturers who had experience using the BL approach in 2012 could mentor new English lecturers on the use and implementation of BL. This resulted in the polytechnic decreasing BL continuous professional development training for English lecturers in 2019. 
(2) Although lecturers applied common means to manage the course and communicate with students through the use of Facebook and Google Classroom, polytechnic students were still passive in engaging and interacting with other students and lecturers in class. They only contacted their lecturers in case they had urgent issues related to their class attendance and final grades.

(3) All lecturers mentioned that they created and implemented activities to promote communication, teamwork, problem-solving, and critical thinking skills. However, 3/5 lecturers thought that it was challenging to perform activities to promote creative thinking skills as most polytechnic students have low English proficiency.

(4) BL had a positive impact on lecturers' delivery. It helped strengthen speaking skills in offline classes for the students and helped to develop professional and interpersonal skills for lecturers. However, BL also caused some negative impacts on lecturers. The reduction in class hours in blended courses has caused the reduction in lecturers' incomes whereas supporting a great number of students within and beyond class. Some lecturers do not have much motivation to conduct active learning and collaborative learning as receiving lower incomes for blended courses.

(5) Students were not provided proper orientation and guidance on the use of the BL approach before the start of the semester. At the same time, some of them were not also autonomous in learning online lessons and actively engaged in offline classes.

\subsection{Survey findings: Perspectives from polytechnic students}

As seen in Figure 1, approximately $80 \%$ to $84 \%$ of respondents were satisfied with the overall course information (the use of the BL approach, Course Objectives (CO) and Course Learning Outcomes (CLO), Assessment, Topics, and Course Duration), which was well demonstrated and communicated at the beginning of the course.

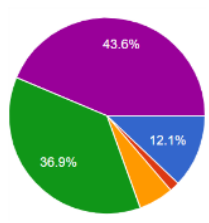

BL approach

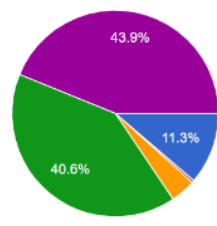

CO and CLO

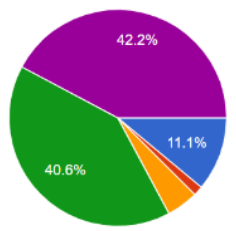

Assessment

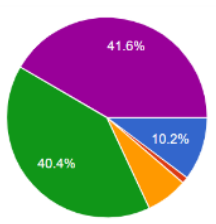

Topics

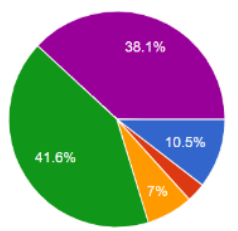

Course

Duration

Fig. 1. Overall course information

Note: Purple- Completely Agree; Green- Agree; Orange-Neutral; Red- Disagree; Blue-Completely Disagree

Figure 2 illustrates $79.9 \%$ to $82.6 \%$ of the respondents showing their agreement with receiving course learning materials and updated references sufficiently and in a timely manner at the beginning of the course. 


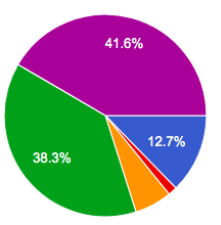

Course materials

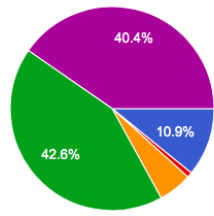

References

Fig. 2. Course material and references

Figure 3 illustrates that students' satisfaction with lecturers' teaching strategies and techniques is from $77.8 \%$ to $80.4 \%$. Teaching strategies and techniques consist of delivering online lectures in a good way, support for students out of class, application of various active learning methods (group work, discussion, presentation, role-play...etc.,), application of online knowledge in-class activities and using official courseware (slides, speaking topics and further discussion questions in offline classes.

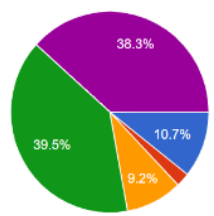

Online lectures
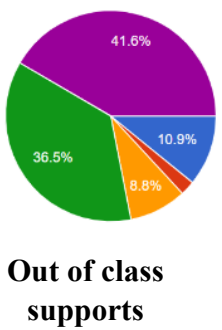

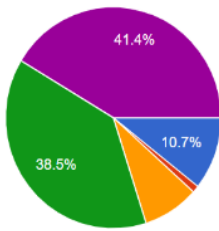

Active learning methods



Applying online knowledge in class activities

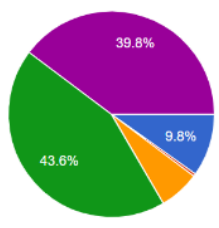

Official courseware

Fig. 3. Instructors' teaching strategies and techniques

When asked whether they would like to continue experiencing the BL approach in other courses, $79.62 \%$ respondents agreed, while $18.87 \%$ disagreed and the remaining respondents had no idea or were still considering. This is a good signal for the polytechnic to promote BL in further English courses in general, and in other courses in the future. However, there emerged three major issues regarding students' demotivation, students' selfstudy capability and 24/7 online support as perceived by the students, when attending the BL-based English Fundamentals course at the polytechnic in the Fall 2019 semester.

First, students' entrance levels at the polytechnic are quite low. They do not have to take any entrance exams for their admission. Students who just graduated from high school with average grades are qualified to enroll in the polytechnic. In addition, they were familiar with the traditional teaching method at high school, in which they were inactive in the class listening to the lecture. In the first semester at the polytechnic, they were exposed to BL requiring more self-study capability, technology usage, and limited offline hours. As a result, demotivation was found among students taking English Fundamentals courses. This finding agreed with the study of Rasskazova (2019), in which online components were seen as a demotivating tool. However, this finding did not resonate with many previous studies in which BL motivated students to interact and engage in the language learning process (Akbarov, Gönen \& Aydoğan, 2018; Banditvilai, 2016; Ja'ashan, 2015). Therefore, it is necessary that the polytechnic invest more time to conduct more research on whether BL made students demotivated or not.

Second, several students found it difficult to take responsibility for their own learning at home as they can lose their concentration due to many distractions. As a result, they may not 
view the full lesson videos or fully comprehend the video contents and therefore be insufficiently prepared for active learning activities in offline classes. This is consistent with the findings of (Vuong et al., 2018), stating that students found it difficult in self-regulated learning. Similarly, Chao et al. (2015) indicated "it was difficult to ensure that students had truly previewed the video". As such, the polytechnic should develop a scheme to control and ensure sufficient preparation by students prior to the class.

Last but not least, they pointed out that there were no 24/7 online supports to explain and deal with issues arising when learning online at home. As stated above, the students' level of English competence is quite low, so they are not able to learn by themselves. This challenge also aligned with the report by Bhagat et al. (2016) in which it claimed that lack of instant help from lecturers could be an obstacle for students during student's self-study time.

\section{Conclusion}

The polytechnic lecturers showed that applying BL in the English Fundamentals course had a positive impact on the teaching approach in the English Fundamentals course. BL also promoted communication, teamwork, critical thinking and problems solving skills for students. Meanwhile, most polytechnic students commented that BL not only developed student's self-autonomy but also brought comfort and flexibility for them. However, there are key issues mentioned in the findings above. Hence, several recommendations are offered as follows: (1) Organize both official BL training workshops and academic meetings for lecturers, and BL orientation workshops for fresh students every semester; (2) Find appropriate ways to balance the number of offline class hours and the incomes s to motivate lecturers to pursue BL in the long term; (3) Offer 24/7 online mentoring/tutoring for fresh students as they online self-study lessons at home. Lastly, lecturers and students in this study strongly agree to experience other BL based courses at the polytechnic in the future. This study makes a valuable contribution to the educational institution's leaders and program administrators by reviewing the effectiveness of BL implementation in the English Fundamentals course by providing the perspectives of lecturers and students from Hanoi campus.

Although this research was carefully developed, there are two existing limitations. First, the respondent rate of the survey was not high (32.6\%) as 489 over 1500 participants responded to the survey. The reason for the low respondent rate was caused by the fall break and the short period of time for conducting the online survey (from 31st December 2019 to 10th January 2020). Second, the scope of this study was limited to non-English major fresh students and full-time EFL lecturers at the polytechnic, Hanoi campus; thus the study results could not be generalized to all non-English major fresh students and all full-time EFL lecturers at all campuses of the polytechnic.

To address these limitations, the researchers should conduct a comparative study to explore student and lecturer's perceptions on BL implementation in English Fundamentals course at all campuses of the polytechnic (Hanoi, Ho Chi Minh, Can Tho, Da Nang and Tay Nguyen).

\section{References}

Akbarov, A., Gönen, K., \& Aydogan, H. (2018). Students' Attitudes toward Blended Learning in EFL Context. Acta Didactica Napocensia, 11(1), 61-68. 
Albiladi, W. S., \& Alshareef, K. K. (2019). BL in English Teaching and Learning : A Review of the Current Literature. Journal of Language Teaching and Research, Vol. 10, p. 232. https://doi.org/10.17507/jltr.1002.03

Alebaikan, R., \& Troudi, S. (2010). Blended learning in Saudi universities: challenges and perspectives. ALT-J, 18(1), 49-59.

Allen, I. E., Seaman, J., \& Garrett, R. (2007). Blending in: The extent and promise of blended education in the United States. Sloan Consortium. PO Box 1238, Newburyport, MA 01950.

Al Zumor, A. W. Q., Al Refaai, I. K., Eddin, E. A. B., \& Al-Rahman, F. H. A. (2013). EFL Students' Perceptions of a Blended Learning Environment: Advantages, Limitations and Suggestions for Improvement. English Language Teaching, 6(10), 95-110.

Banditvilai, C. (2016). Enhancing Students' Language Skills through Blended Learning. Electronic Journal of e-Learning, 14(3), 220-229.

Betts, K. (2014). Factors influencing faculty participation \& retention in online \& blended education. Online Journal of Distance Learning Administration, 17(1), 1.

Bhagat, K. K., Chang, C. N., \& Chang, C. Y. (2016). The impact of the flipped classroom on mathematics concept learning in high school. Educational Technology \& Society, 19(3), 134142.

Chao, C. Y., Chen, Y. T., \& Chuang, K. Y. (2015). Exploring students' learning attitude and achievement in flipped learning supported computer aided design curriculum: a study in high school engineering education. Computer Applications in Engineering Education, 23(4), 514-526.

Gruba, P., \& Hinkelman, D. (2012). Blending technologies in second language classrooms. Palgrave Macmillan.

Hoang, N. T. (2015. EFL teachers' perceptions and experiences of BL in a Vietnamese university. Office of Education Research; Faculty of Education. Retrieved from http://eprints.qut.edu.au/83945/

Hong, K., \& Samimy, K., (2010). The influence of L2 teachers' use of CALL modes on language learners' reactions to BL. CALICO Journal, 27(2), p.328-348.

Ivankova, N. V., Creswell, J. W., \& Stick, S. L. (2006). Using mixed-methods sequential explanatory design: From theory to practice. Field methods, 18(1), 3-20.

Ja'ashan, M. M. N. H. (2015). Perceptions and Attitudes Towards Blended Learning for English Courses: A Case Study of Students at University of Bisha. English Language Teaching, 8(9), 40-50.

Johnson, C. P., \& Marsh, D. (2014). Blended Language Learning: An Effective Solution but Not without Its Challenges. Higher Learning Research Communications, 4(3), 23-41.

Joosten, T. M., Barth, D., Harness, L., \& Weber, N. L. (2014). The impact of instructional development and training for blended teaching on course effectiveness. Blended learning: Research perspectives, 2, 173-189. 
MacDonald, J. (2008). BL and online tutoring: A good practice guide. Aldershot, UK: Gower.

Modell, S. (2005). Triangulation between case study and survey methods in management accounting research: An assessment of validity implications. Management accounting research, 16(2), 231-254.

Moskal, P. D., \& Cavanagh, T. B. (2014). Scaling BL evaluation beyond the university. BL: Research perspectives, 2, 34-51.

Moskal, P., Dziuban, C., \& Hartman, J. (2013). Blended learning: A dangerous idea?. The Internet and Higher Education, 18, 15-23.

Murphy, P. (2008). Defining pedagogy. In K. Hall, P. Murphy \& J. Soler (Eds.), Pedagogy and practice: Culture and identities. Milton Keynes: Sage publication.

Partridge, H., Ponting, D., \& McCay, M. (2011). Good practice report: BL. Australian Learning and Teaching Council. Retrieved from http://eprints.qut.edu.au/47566/1/47566.pdf

Rasskazova, T., Dubina, N., Yedik, N., \& Aksenova, V. (2019). BLENDED LEARNING IN L2: MOTIVATION OR DE-MOTIVATION?. INTED2019 Proceedings, 6379-6384.

Rubio, F., \& Thoms, J. J. (2014). Hybrid language teaching and learning: Exploring theoretical, pedagogical and curricular issues.

Sharma, P. (2010). Key Concepts in ELT. ELT Journal Volume 64/4 p.456. Oxford University Press.

Stracke, E. (2007). A road to understanding: A qualitative study into why learners drop out of a blended language learning (BLL) environment. ReCALL, 19(1), 57-78.

Taylor, J. A., \& Newton, D. (2013). Beyond BL: A case study of institutional change at an Australian regional university. The Internet and Higher Education, 18, 54-60.

Vaughan, N. D., Cleveland-Innes, M., \& Garrison, D. R. (2013). Teaching in blended learning environments: Creating and sustaining communities of inquiry. Athabasca University Press.

Vietnamese Government. (2012). Quyet dinh phe duyet "chien luoc phat trien giao duc 20112020' (Descision on approving strategies for developing Vietnamese education period 20112020). Hanoi, Vietnam.

Vuong, N. H. A., Tan, C. K., \& Lee, K. W. (2018). Students' Perceived Challenges of Attending a Flipped EFL Classroom in Viet Nam. Theory and Practice in Language Studies, 8(11), 1504-1510.

\section{Appendix}

Previous Studies on Blended Learning for Teaching English 


\begin{tabular}{|c|c|c|}
\hline Papers & Finding & $\begin{array}{c}\text { Limitation/ } \\
\text { Further Study }\end{array}$ \\
\hline $\begin{array}{l}\text { Al Zumor } \\
\text { et al. } \\
(2013)\end{array}$ & $\begin{array}{l}\text { The results indicate "the clear } \\
\text { advantages of this new experience in } \\
\text { broadening students' reading } \\
\text { opportunities and enriching their } \\
\text { English vocabulary". The problems of } \\
\text { BL are followed by practical } \\
\text { suggestion including "solving } \\
\text { technical problems, providing proper } \\
\text { training to students, increasing the } \\
\text { number of labs, and recognizing } \\
\text { excellent performance of both } \\
\text { instructors and students." }\end{array}$ & $\begin{array}{l}\text { Further studies are conducted to } \\
\text { examine whether "translating } \\
\text { these suggestions into an action } \\
\text { plan will enhance the effectiveness } \\
\text { of using Blended Learning to } \\
\text { create supportive learning } \\
\text { opportunities for language } \\
\text { learners." }\end{array}$ \\
\hline $\begin{array}{l}\text { Banditvilai } \\
(2016)\end{array}$ & $\begin{array}{l}\text { "Online practice is directly beneficial } \\
\text { to enhance the four language learning } \\
\text { skills as well as autonomous learning } \\
\text { and learner motivation." }\end{array}$ & $\begin{array}{l}\text { The limitation is "limited only to } \\
\text { one class of Kasetsart University } \\
\text { (Thailand) students." }\end{array}$ \\
\hline $\begin{array}{c}\text { Ja'ashan } \\
\text { (2015) }\end{array}$ & $\begin{array}{l}\text { The result illustrates "the students' } \\
\text { satisfaction with BL as enhancing } \\
\text { their English language skills and } \\
\text { making English learning } \\
\text { collaborative, interactive and } \\
\text { interesting". It is also noted that } \\
\text { students' negative attitudes towards } \\
\text { BL is caused by time consuming than }\end{array}$ & $\begin{array}{l}\text { "It needs more research and } \\
\text { development that address types of } \\
\text { BL from different aspects such as } \\
\text { effective infrastructure and } \\
\text { training of both instructors and } \\
\text { learners with efficient skills in } \\
\text { teaching and learning." }\end{array}$ \\
\hline $\begin{array}{c}\text { Vuong et al. } \\
(2018)\end{array}$ & $\begin{array}{l}\text { It is highlighted that "Vietnamese } \\
\text { students encounter challenges when } \\
\text { attending the flipped classroom } \\
\text { including difficulty in self-regulated } \\
\text { learning, heavy learning workload, } \\
\text { lack of immediate support and lack of } \\
\text { ICT resources." }\end{array}$ & $\begin{array}{l}\text { "The study was only conducted } \\
\text { with a small group of participants } \\
\text { from only one university in Viet } \\
\text { Nam". "The research was merely } \\
\text { based on the qualitative data, } \\
\text { lacking the triangulation from } \\
\text { other data resources". }\end{array}$ \\
\hline
\end{tabular}

